\title{
Effects of climate and historical adaptation measures on barley yield trends in Finland
}

\author{
Taru Palosuo*, Reimund P. Rötter, Tapio Salo, Pirjo Peltonen-Sainio, Fulu Tao, \\ Heikki Lehtonen
}

Natural Resources Institute Finland (Luke), 00790 Helsinki, Finland

\begin{abstract}
In this study, the WOFOST crop simulation model was used together with comprehensive empirical databases on barley Hordeum vulgare L. to study the contributions of different yield-determining and -limiting factors to observed trends of barley yield in Finland from 1988 to 2008. Simulations were performed at 3 study sites representing different agro-ecological zones, and compared with the data from experimental sites and that reported by local farmers. Yield gaps between simulated potential yields and farmers' yields and their trends were assessed. Positive observed yield trends of Finnish barley mostly resulted from the development and usage of new, high-yielding cultivars. Simulated trends in climatic potential and water-limited potential yields of individual cultivars showed a slight declining trend. Yield gaps showed an increasing trend in 2 out of 3 study areas. Since the mid-1990s, a major reason for this has been the lack of market and policy incentives favouring crop management decisions, i.e. annual fertilisation, soil maintenance, drainage and crop rotation decisions, aiming for higher yields. The study indicates potential options for increasing or maintaining barley yields in the future. The breeding of new climateresilient cultivars is the primary option. However, this needs to work alongside overall adjustments to farm management and must be supported by financial incentives for farmers to increase yields.
\end{abstract}

KEY WORDS: Adaptation - Climate - Crop simulation modelling · Plant breeding · Spring barley · Yield gap Resale or republication not permitted without written consent of the publisher

\section{INTRODUCTION}

Worldwide agriculture and crop production have experienced enormous changes in recent decades. These changes have mainly been driven by accelerated technological progress and economic policy convergence. In Europe, important changes include more stringent environmental policies and progress in plant breeding, in conjunction with global environmental change affecting agricultural production (Brisson et al. 2010, Olesen et al. 2011). Evidence of the already changing climate has continuously accumulated (IPCC 2013) and farmers have largely started adapting to these changes by adjusting agronomic practices and the crop species and cultivars they grow (Bindi \& Olesen 2011). For instance, in the US Corn Belt, it has been found that the adoption of cultivars with a longer grain-filling period and the shift to earlier planting dates explain the yield increases over the last few decades to a large extent (Sacks \& Kucharik 2011). In Finland, farmers have adjusted to climate warming by planting spring cereals and other crops earlier (Kaukoranta \& Hakala 2008), and they have increasingly replaced earliermaturing barley Hordeum vulgare L. with latermaturing wheat Triticum aestivum L. (PeltonenSainio \& Jauhiainen 2014).

A comprehensive quantitative analysis of the various climatic and non-climatic factors contributing to past yield trends would be needed to increase under- 
standing of promising future management interventions. It is, however, generally difficult to separate the effects of changes in individual yield-determining and -limiting factors when several factors are changing at the same time. Process-based crop simulation models that describe the interactions of crop genotype, management and environmental factors are the most appropriate tools for identifying and quantifying the contributions of individual factors to yield. In terms of climate change, these tools are especially valuable, as in combination with climate projections they can be applied to evaluate various adaptation options for different crops, as demonstrated for wheat in the UK (Semenov et al. 2014) or for barley in Finland (Rötter et al. 2011).

In Finland, spring barley is currently the most important cereal crop, covering about one-quarter of the total cultivated area (Matilda Agricultural Statistics 2014). It is cultivated almost up to the Arctic Circle $\left(66^{\circ} 33^{\prime} \mathrm{N}\right)$ with the main cultivation areas being in south-western, western and south-eastern Finland (see Fig. 1). There is significant diversity in both 2row and 6-row cultivars with different sensitivities to the weather (Hakala et al. 2012). Barley yields increased markedly from the 1960s to the mid-1990s, when the rate of increase slowed or even stagnated (Peltonen-Sainio et al. 2009a), and there remains a considerable yield gap (van Ittersum et al. 2013) between potential yields and actual yields observed on farmers' fields, which is even widening in various sub-regions of Finland (Peltonen-Sainio et al. 2009a). Potential yield is here defined following the definition of Evans \& Fischer (1999) as the maximum yield that could be reached by a crop in given environments with the assumption that nutrients and water are non-limiting, and pests, diseases, weeds, lodging, and other stresses are effectively controlled.

Climate change in Northern Europe, including Finland, is very likely to lead to a longer growing period (Peltonen-Sainio et al. 2009b, Bindi \& Olesen 2011), and precipitation is expected to increase markedly, with more in the winter than the summer (Lehtonen et al. 2014). However, increases in precipitation at sowing or harvest and increased variability of temperatures, and precipitation might considerably hinder possible yield gains provided by the longer growing season (van Oort et al. 2012), especially if plant breeding and management practices do not adjust adequately or in a timely fashion in response to the challenges posed by such changes in climatic variability (Rötter et al. 2011).

The specific objectives of this study were: (1) to identify the contribution of changing climatic condi- tions, changes in barley cultivar characteristics, and crop and soil management to observed yield trends in Finland in recent decades, (2) to assess the development of yield gaps and major factors contributing to them, and, as a result, (3) to explore potential options for increasing and/or maintaining barley yields in the future. To this end, a simulation approach combined with comprehensive empirical barley yield and management databases from 3 regions representing different agro-ecological zones in Finland were applied. Data included $42 \mathrm{yr}$ time series from the experimental sites and $21 \mathrm{yr}$ time series of farmers' barley cultivation data that allowed for the assessment of long-term trends.

\section{MATERIALS AND METHODS}

\subsection{General approach}

First, the observed yields at experimental sites (official variety trials) - along with data reported by local farmers - were gathered, and long-term yield trends exhibiting genotype $\times$ environment $\times$ management effects were identified. Then the WOFOST crop simulation model (Boogaard et al. 1998) was used to study the degree to which changes in the following affected observed yield trends: (1) environmental conditions, i.e. climate (weather patterns, frost, precipitation at harvesting) and soil types used for barley production, (2) genotype (effect of changed cultivars as identified from the empirical variety trial and on farm data), and (3) agro-management (sowing dates and fertiliser use). Yield gaps resulting from sub-optimal agronomic management (van Ittersum \& Rabbinge 1997) were analysed by calculating the difference between simulated potential and water-limited yields (that assume optimum management) and observed yields from farmers' fields in the 3 study regions.

\subsection{Data}

\subsubsection{Experimental sites}

The barley data from 3 experimental sites of Finnish official variety trials (Kangas et al. 2010) Jokioinen, Laukaa and Ruukki (Fig. 1, Table 1) — for the period from 1970 to 2011 were used to analyse cultivar properties such as phenological classification (i.e. early, intermediate and late-maturing cultivars) and yield potentials. The data applied from the study 


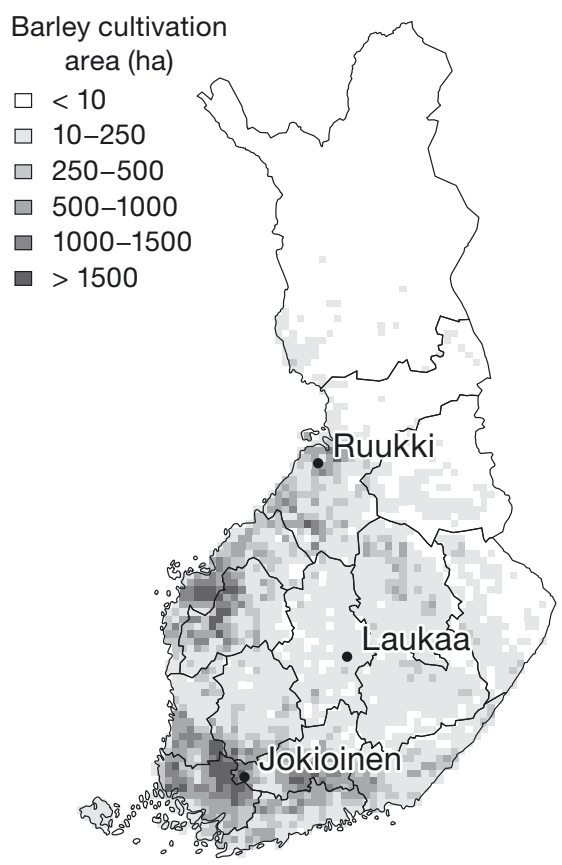

Fig. 1. The 3 experimental sites, the ELY Centre (Centres for Economic Development, Transport and the Environment) regions, and the barley Hordeum vulgare L. cultivation areas as a $10 \times 10 \mathrm{~km}$ grid for the whole of Finland (2007)

sites consisted of information on cultivar, sowing and harvesting dates, durations from sowing to ripening (Z92 according to Zadoks et al. 1974), yields ( $\mathrm{t} \mathrm{ha}^{-1}$ ) and soil types (based on soil texture classes).

\subsubsection{Farmers' barley cultivation data}

The data regarding the barley yields of farmers was sourced from the Evira database (Evira 2012) that was originally collected for the monitoring of cereal grain quality. The 1998-2008 data used covered the 3 ELY Centre (Centres for Economic Devel- opment, Transport and the Environment) regions where the selected experimental sites were located. The ELY Centres for Jokioinen, Laukaa and Ruukki are Häme, Central Finland and North Ostrobothnia, respectively (Fig. 1). The average number (range) of annual yield data cases from these regions were 59 (11-144), 17 (7-33) and 39 (16-75), respectively. The yield estimates and cultivars used were reported to the database by farmers.

The Evira data also contained soil types, estimated according to the Finnish agronomic soil test protocol following the Finnish soil classification based on soil textures (Peltovuori 2008). On average over the $21 \mathrm{yr}$ period, soil type data was available for barley yield observations in $97 \%$ of the cases. Annually this ranged from 74 to $100 \%$, depending on the site and year. In addition, farmer-reported sowing dates and applied fertiliser rates were also available in the dataset.

\subsubsection{Weather data}

Daily weather data for the period from 1971 to 2010 from the 3 Finnish Meteorological Institute (FMI) weather stations at Jokioinen Observatory, Laukaa and Oulu Airport were utilised. Weather data consisted of daily minimum and maximum temperatures $\left({ }^{\circ} \mathrm{C}\right)$, measured global radiation $\left(\mathrm{MJ} \mathrm{m} \mathrm{m}^{-2}\right)$, daily amount of precipitation (mm), early morning vapour pressure $(\mathrm{kPa})$, and mean daily wind speed $\left(\mathrm{m} \mathrm{s}^{-1}\right)$.

\subsection{WOFOST crop simulation model}

The WOFOST (World Food Studies) model (Boogaard et al. 1998) was used, which has been previously calibrated (Rötter et al. 2011), tested (Rötter et

Table 1. Characteristics of experimental sites: longitude, latitude, altitude and their long-term agro-climatic conditions for the period 1971-2011 calculated based on data from the Finnish Meteorological Institute. ${ }^{*} \mathrm{p}<0.05,{ }^{* *} \mathrm{p}<0.01,{ }^{* * *} \mathrm{p}<0.001$; $\mathrm{p}>0.05$ is not indicated

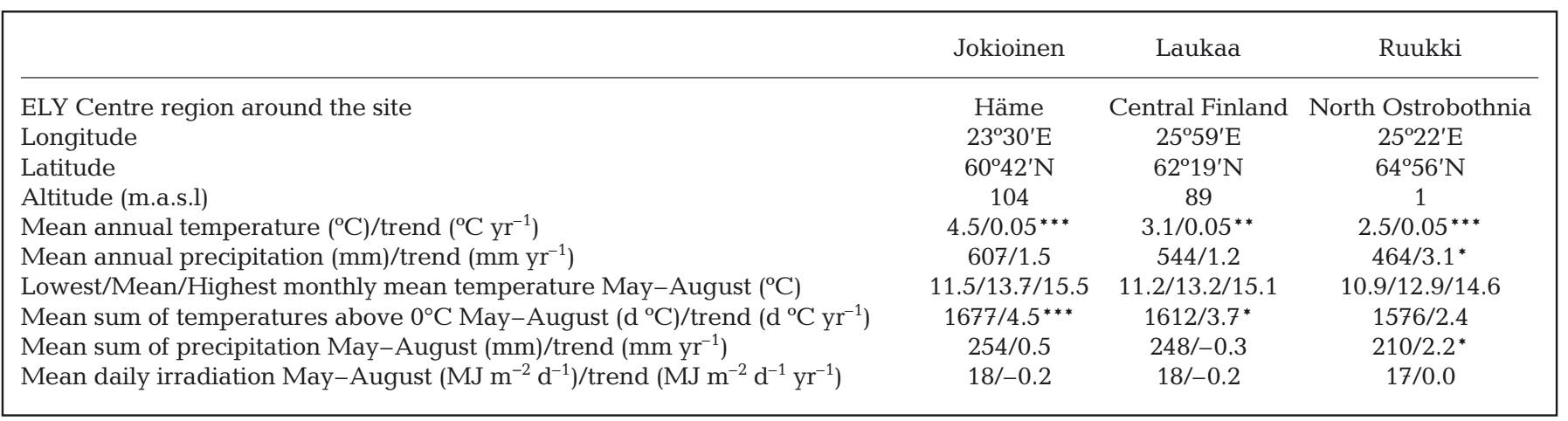


al. 2012) and applied (Rötter et al. 2013) for barley in Finland.

The model dynamically describes the phenological development, growth and yield formation of a crop from emergence to maturity (at a daily time step), on the basis of crop genetic characteristics, management practices and environmental conditions. The major processes incorporated are phenological development, $\mathrm{CO}_{2}$ assimilation, respiration, partitioning of assimilates to various plant organs, yield formation and evapotranspiration. In the model, crop yields can be calculated for 3 different production situations: potential, water-limited, and nutrientlimited production (van Ittersum \& Rabbinge 1997). The present study applied simulation results for potential and water-limited yields, and estimated the nutrient-limited yield levels as described in Section 2.4.4 'Agro-management'.

\subsection{Simulation set-up to identify the contributions of different factors}

\subsubsection{Cultivars}

A total of 74 cultivars used by farmers were identified in the Evira dataset, out of which 66, i.e. $89 \%$, could also be identified in the variety trial dataset. The variety trial data from the Jokioinen experimental site with the widest set of cultivars was used for classifying the cultivars used by farmers into the cat-

Table 2. Barley Hordeum vulgare L. cultivar group-specific WOFOST crop parameters used. Other parameters were kept constant and were based on Boons-Prins et al. (1993). Cultivar differences in this simplified approach are described with differences in thermal requirements (TSUMs), photosynthetic rate (AMAX) and early growth vigour through the leaf area index (LAI) parameter in the exponential leaf growth phase (RGRLAI)

\begin{tabular}{|c|c|c|c|c|c|}
\hline Cultivar group & $\begin{array}{c}\text { Example } \\
\text { cultivar }\end{array}$ & TSUM1 $^{\mathrm{a}}$ & TSUM $^{\mathrm{b}}$ & $\mathrm{AMAX}^{\mathrm{C}}$ & RGRLAI $^{\mathrm{d}}$ \\
\hline \multicolumn{6}{|l|}{ Historical } \\
\hline Early & Otra & 620 & 530 & 28 & 0.0080 \\
\hline Intermediate & Pomo & 650 & 600 & 28 & 0.0078 \\
\hline Late & Kustaa & 690 & 610 & 35 & 0.0080 \\
\hline \multicolumn{6}{|l|}{ Modern } \\
\hline Early & Rolfi & 630 & 540 & 35 & 0.0080 \\
\hline Intermediate & Scarlett & 700 & 630 & 35 & 0.0080 \\
\hline Late & Tocada & 730 & 640 & 35 & 0.0080 \\
\hline $\begin{array}{l}\text { aTemperature } \\
\text { (Z65 accordin } \\
\text { bemperature } \\
{ }^{\mathrm{C}} \text { Maximum leaf } \\
{ }^{\mathrm{d}} \text { Maximum rela }\end{array}$ & $\begin{array}{l}\mathrm{m} \text { from em } \\
\text { to Zadoks } \\
\mathrm{m} \text { from an } \\
\mathrm{O}_{2} \text { assimi } \\
\text { ve increas }\end{array}$ & $\begin{array}{l}\text { ergence to } \\
\text { t al. }(1974 \\
\text { hesis to } \mathrm{m} \\
\text { ation rate } \\
\text { in LAI }(\mathrm{h}\end{array}$ & $\begin{array}{l}\text { anthesis ( } \\
\text { aturity }\left({ }^{\circ} \mathrm{D}\right. \\
\text { (kg ha } \\
\text { a ha } \mathrm{ha}^{-1} \mathrm{~d}^{-1} \text { ) }\end{array}$ & $\begin{array}{l}\text { degree do } \\
(\mathrm{Z} 91) \\
\left.{ }^{1}\right)\end{array}$ & ays, $\left.{ }^{\circ} \mathrm{D}\right)$ \\
\hline
\end{tabular}

egories of early-, intermediate- and late-maturing cultivars. The cultivars were ranked annually according to the length of their growth cycle, i.e. duration (in days) from sowing to ripening. The median relative ranks of each cultivar over all years were then used to determine the phenological class of cultivar: early- and late-maturing cultivars belong to the earliest and latest quartiles, respectively, while the rest were classified as intermediate (medium-maturing).

The cultivars were also classified as historical or modern, according to their first occurrences in the trials. Cultivars introduced to variety trials prior to 1990 were classified as 'historical', while the rest were classified as 'modern' cultivars.

The above classification, which was based on variety trial data, was applied for cultivars grown by farmers. Annual shares of those classes used by farmers were used to weigh the simulated model results of the cultivar groups to show the effect of the changed cultivar use on long-term yield trends. Also, the properties of the most commonly used cultivars in the study regions were summarised to achieve an initial picture of the factors driving farmers' cultivar choices (see Table S1 in the Supplement at www.intres.com/articles/suppl/c065p221_supp.pdf).

The WOFOST crop parameter set, i.e. the model parameters describing the properties of the barley crop, employed the basic crop parameter set from a compilation of European data (Boons-Prins et al. 1993) and further refinement carried out for Finnish cultivars described by Rötter et al. $(2011,2013)$ based on variety trial data (Kangas et al. 2010, Hakala et al. 2012) and other datasets on Finnish barley (unpublished working documents and field log books, Natural Resources Institute Finland). The phenology of the various maturity classes of Finnish barley ( 6 different cultivar groups) was determined on the basis of official variety trial data (Table 2). Testing of the cultivar grouping is presented in Fig. S1 in the Supplement at www.int-res.com/articles/ suppl/c065p201_supp.pdf. In addition, testing of WOFOST performance on Finnish barley has been presented by Rötter et al. (2012).

\subsubsection{Climate effects}

Trends in simulated potential and waterlimited yields were taken as an indication of the possible impact of changed weather conditions on long-term yield trends. In these simulations, weather data and sowing 
dates derived by applying weather-based rules were the only driving factors for the differences between years. Simulations were performed for the 2 different soil types, heavy clay and coarse sand, that represent the extreme ends of prevailing soil types and thereby show the range of potential impacts in different soils.

To cover the effects of weather occurrences whose impacts were not captured by the simulation model, the trends in frost and weather conditions during harvest time were studied separately. Linear regression analysis of the last date of frost (daily minimum temperature $<0^{\circ} \mathrm{C}$ ), precipitation sums from -5 to $+14 \mathrm{~d}$ around harvests, as well as maximum daily precipitation from -10 to $+10 \mathrm{~d}$ around harvests was performed. Harvest conditions were assessed separately for historical early and modern late cultivar groups.

\subsubsection{Soil types}

WOFOST simulations for the experimental sites were performed for the set of the most representative soil types at the study sites: clay loam, silty sand and fine sand. Water-limited simulations were also made for heavy clay and coarse sandy soil, to see the longterm effect of climate on the yields on soils with different textures. Soil parameters, e.g. those related to water-holding capacity, for heavy clay and coarse sandy soil were adopted from previous studies of the same soil types (Rötter et al. 2011, 2013). Initial soil moisture content at the beginning of simulations was set to be equal to soil moisture at field capacity in the deeper soil layers and $75 \%$ of the soil moisture content between wilting point and field capacity for the topmost $10 \mathrm{~cm}$ soil layer.

\subsubsection{Agro-management}

Sowing dates used in simulations were determined each year following the procedure created by Carter \& Saarikko (1996) for calculating the date when the moving average of daily mean temperature exceeded the temperature limit $\left(8^{\circ} \mathrm{C}\right)$. Trends in sowing dates were also analysed from the 21 yr Evira dataset and the effect of those trends on yields were simulated with WOFOST. Simulations were performed by taking the sowing dates for the start and end years 1988 and 2008 from a linear regression line fitted on the Evira observations, and then simulating the yield series for the period from 1988 to 2008 with these fixed sowing dates.
Nitrogen (N) and phosphorus (P) fertiliser application rates applied by farmers were studied. The maximum yields achievable with the application rates were estimated based on the calculated nutrient uptake by crops, assuming there were no interannual variations in nutrient uptake from soil reserves and recovery efficiencies of nutrients from applied fertilisers. In this simplified approach, rainfall conditions and water uptake of crops did not affect the nutrient uptake estimates, but the values show the nutrient-limited yield levels in otherwise optimal conditions. The values applied and data sources are presented in Table 3. This is comparable to the QUEFTS approach (Janssen et al. 1990) originally developed for quantitative evaluation of the fertility of tropical soils and which has been applied, for instance, for different cereals by Pathak et al. (2003).

Crop protection was assumed to be fully effective and was not further considered in the simulation setup as the Evira dataset did not provide sufficient information for a thorough analysis.

\subsubsection{Yield gaps}

Yield gaps between the simulated potential and water-limited yield levels (i.e. assuming other management factors are optimal) and between simulated water-limited and observed farmers' yields were calculated by region, with point-based simulations using the weather data available for the research sites at Jokioinen, Laukaa and Ruukki, and the most representative soil types, which were clay loam for Häme, silty sand for Central Finland and fine sand for North Ostrobothnia. Simulations were made for all 6 cultivar groups and they were weighted according to the annual usage of the cultivars. Relative yield gaps at the end years of the time series were calculated and presented as percentages: farmers' yields per water-limited simulated yields and waterlimited simulated yields per simulated potential yields.

\section{RESULTS}

\subsection{Observed yield trends}

Barley yields, both at the experimental sites and in farmers' fields, have been increasing over the past $40 \mathrm{yr}$, with farmers' yields in the surrounding ELY regions being on average a third lower than those at the experimental sites in Jokioinen, Laukaa and 
Table 3. Parameter values and data used to calculate nitrogen- and phosphorus-limited barley Hordeum vulgare L. yield estimates. DM indicates dry matter. (-) Unitless

\begin{tabular}{|c|c|c|c|c|}
\hline Parameter & Häme & $\begin{array}{l}\text { Central } \\
\text { Finland }\end{array}$ & $\begin{array}{c}\text { North } \\
\text { Ostrobothnia }\end{array}$ & References \\
\hline Most representative soil type & Clay loam & Silty sand & Fine sand & \\
\hline Grain $N$ content $\left(\mathrm{g} \mathrm{g}^{-1}\right)$ & 0.019 & 0.019 & 0.020 & $\begin{array}{l}\text { Salo et al. (2014), their Table 6, average } \\
\text { 2002-2012 }\end{array}$ \\
\hline $\mathrm{N}$ in vegetative organs $\left(\mathrm{g} \mathrm{g}^{-1}\right)$ & 0.006 & 0.006 & 0.006 & $\begin{array}{l}\text { Feed tables }{ }^{\mathrm{a}} \text {; straw, crude protein } \\
40 \mathrm{~g} \mathrm{~kg} \mathrm{DM}^{-1}\end{array}$ \\
\hline $\mathrm{N}$ uptake from soil reserves $\left(\mathrm{kg} \mathrm{N} \mathrm{ha}^{-1}\right)$ & $50 / 50 \rightarrow 45^{\mathrm{b}}$ & $50 / 50 \rightarrow 45^{\mathrm{b}}$ & $50 / 50 \rightarrow 45^{\mathrm{b}}$ & Lindén et al. (1992), their Fig. 3 \\
\hline $\mathrm{N}$ recovery efficiency $(-)$ & 0.58 & 0.52 & 0.52 & Muurinen et al. (2007) \\
\hline \multicolumn{5}{|c|}{ (two-row barley) (six-row barley) (six-row barley) } \\
\hline Mean annual $\mathrm{N}$ fertiliser amounts $\left(\mathrm{kg} \mathrm{N} \mathrm{ha}^{-1}\right)$ & Fig. 6 & Fig. 6 & Fig. 6 & Evira data \\
\hline Grain P content $\left(\mathrm{g} \mathrm{g}^{-1}\right)$ & 0.0034 & 0.0037 & 0.0035 & $\begin{array}{l}\text { Salo et al. (2014), their Fig. 12, average } \\
\text { 2002-2012 }\end{array}$ \\
\hline$P$ in vegetative organs $\left(\mathrm{g} \mathrm{g}^{-1}\right)$ & 0.001 & 0.001 & 0.001 & Feed tables ${ }^{\mathrm{a}}$; straw, P $1.0 \mathrm{~g} \mathrm{~kg}^{-1} \mathrm{DM}$ \\
\hline $\mathrm{P}$ uptake from soil reserves $\left(\mathrm{kg} \mathrm{P} \mathrm{ha}^{-1}\right)$ & 24.4 & 20 & 26.2 & Ylivainio et al. (2014), their Table 3 \\
\hline$P$ recovery efficiency $(-)$ & $0.15 / 0.10$ & $0.15 / 0.10$ & $0.15 / 0.10$ & Saarela et al. (2008) \\
\hline Mean annual $\mathrm{P}$ fertiliser amounts $\left(\mathrm{kg} \mathrm{P} \mathrm{ha}^{-1}\right)$ & Fig. 6 & Fig. 6 & Fig. 6 & Evira data \\
\hline Harvest index (-) & 0.5 & 0.5 & 0.5 & $\begin{array}{l}\text { Rough estimates based on Peltonen- } \\
\text { Sainio et al. (2008) }\end{array}$ \\
\hline
\end{tabular}
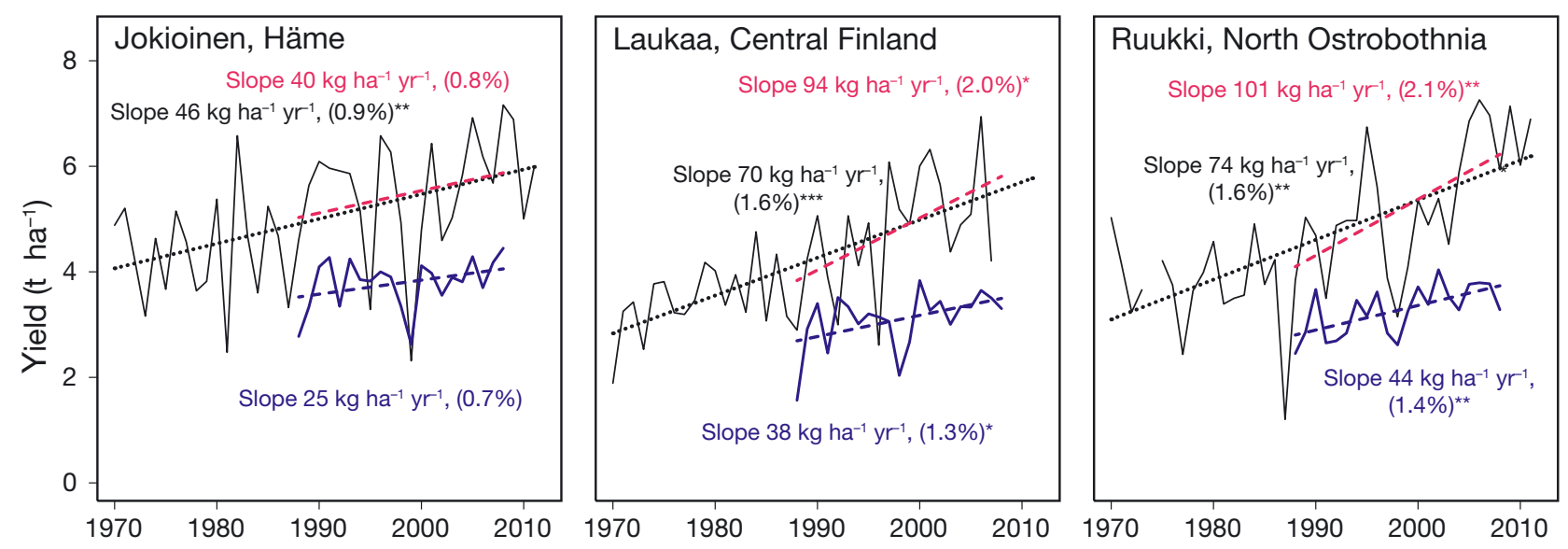

Fig. 2. Mean barley Hordeum vulgare L. yields at the 3 experimental sites (black solid lines) from 1970 to 2011 with trends over the whole period (black dotted line), trends over the period from 1988 to 2008 (pink dashed line), and mean regional yields of the farmers in the surrounding ELY Centre area (blue solid line) with trend (blue dashed line). Variety trial data included all tested cultivars in all soil types of the study sites. ${ }^{*} p<0.05 ;{ }^{* *} p<0.01 ;{ }^{* * *} p<0.001 ; p>0.05$ is not indicated

Ruukki (Fig. 2). The difference between the yields at the experimental sites and farms increased during the study period, as the yield increases at the experimental sites were higher than the increases in the barley yields in the farmers' fields in the regions. At the Jokioinen experimental site, the increase from
1988 to 2008 was lower than the longer-term yield increases (1970 to 2011), whereas for Laukaa and Ruukki the long-term increases were lower (Fig. 2, Table 4). Interannual variation in variety trial yields was higher than the interannual variation in farmers' yields (Table 5). 
Table 4. Summary of the barley Hordeum vulgare L. yield trends $\left(\mathrm{kg} \mathrm{ha}^{-1} \mathrm{yr}^{-1}\right)$ driven by different factors studied. HE: historical early cultivars, MI: modern intermediate cultivars, ML: modern late cultivars; WL yield: water-limited yield. ${ }^{*} \mathrm{p}<0.05,{ }^{* *} \mathrm{p}<0.01$, ${ }^{* * *} \mathrm{p}<0.001 ; \mathrm{p}>0.05$ is not indicated

\begin{tabular}{|lcccc|}
\hline & $\begin{array}{c}\text { Fig. in } \\
\text { present } \\
\text { study }\end{array}$ & $\begin{array}{c}\text { Jokioinen } \\
\text { (Häme) }\end{array}$ & $\begin{array}{c}\text { Laukaa } \\
\text { (Central } \\
\text { Finland) }\end{array}$ & $\begin{array}{c}\text { Ruukki } \\
\text { (North } \\
\text { Ostrobothnia) }\end{array}$ \\
\hline Observed yield trends & & & & \\
Farmers' (1988-2008) & Fig. 2 & 25 & $38^{*}$ & $44^{* *}$ \\
Trial site (1988-2008) & Fig. 2 & 40 & $94^{*}$ & $101^{* *}$ \\
Trial site (1970-2011) & Fig. 2 & $46^{* *}$ & $70^{* * *}$ & $74^{* * *}$ \\
Climate effect (1988-2008) & & & & \\
Potential yield, HE & Fig. 3 & -18 & -17 & 14 \\
Potential yield, MI & Fig. 3 & -24 & -13 & 35 \\
WL yield, HE, clay/coarse sandy soil & Fig. 3 & $-18 / 3$ & $-19 / 16$ & $14 / 21$ \\
WL yield, MI, clay/coarse sandy soil & Fig. 3 & $-22 / 2$ & $-30 / 20$ & $35 / 70$ \\
Cultivar effect (1988-2008) & Fig. 5 & $66^{*}$ & 25 & $73^{* *}$ \\
Sowing dates (1988-2008) & & & & 1 \\
WL yield, HE & - & 7 & 5 & 0 \\
WL yield, ML & - & 7 & 6 & 1 \\
\hline
\end{tabular}

Table 5. Interannual variation around the trend lines in Fig. 2 in variety trial barley Hordeum vulgare L. yield data and farmer-reported yields. Parentheses: relative variation, i.e. variation divided by the mean yield $(\%)$

\begin{tabular}{|lcc|}
\hline Study site (region) & $\begin{array}{c}\text { Variety trial } \\
\text { data } \\
\left(\mathrm{kg} \mathrm{ha}^{-1}\right)\end{array}$ & $\begin{array}{c}\text { Farmers' } \\
\text { yields } \\
\left(\mathrm{kg} \mathrm{ha}^{-1}\right)\end{array}$ \\
\hline Jokioinen (Häme) & $\pm 840(17)$ & $\pm 350(9)$ \\
Laukaa (Central Finland) & $\pm 770(19)$ & $\pm 340(11)$ \\
Ruukki (North Ostrobothnia) & $\pm 830(18)$ & $\pm 290(9)$ \\
\hline
\end{tabular}

\subsection{Environmental effects on yield trends}

\subsubsection{Climate effects on potential yields}

Climate effects on simulated long-term (1970 to 2011) potential yields for different barley cultivars were not significant (Table 4). Potential yields while cultivars remained the same saw a slight decrease at all sites (Fig. 3), which reflects the effect of slightly warmer growing season conditions (Table 1) and hence a shortening of the duration of the growth cycle for these cultivars. During the shorter time period (1988 to 2008), the potential yields increased in Ruukki, but decreased at the other sites. The climate effects on water-limited yield trends were more variable. On clay soils, the $40 \mathrm{yr}$ water-limited yield trends were decreasing at all sites, whereas the $20 \mathrm{yr}$ trends were decreasing in Jokioinen and Laukaa but increasing in Ruukki. Water-limited yield trends for the coarse sand soil in Ruukki were all increasing. On the other 2 sites, the long-term water-limited yield trends of the coarse sandy soil were decreasing, except for the historical early maturing cultivar in Laukaa, which was increasing, but $20 \mathrm{yr}$ trends were all increasing. The trends of both the historical early and modern intermediate-maturing cultivars were similar for both soil types at all 3 study sites.

According to our simulations, barley yields on heavy clay soils were hardly ever limited by water availability (Fig. 3) under Finnish conditions. Throughout the almost $40 \mathrm{yr}$ simulation period, there were only $3 \mathrm{yr}$ in Jokioinen, 1 yr in Laukaa and none in Ruukki when the water availability decreased the yields of the modern intermediate cultivars by more than $10 \%$ on clay soils. The water availability effects for the historical early cultivars on clay soils were minor. The effects on coarse sandy soil were greater. Again, the effects were more severe for the modern intermediate than for the historical early cultivar.

\subsubsection{Frost and harvest conditions}

The last date of frost (daily minimum temperature $<0^{\circ} \mathrm{C}$ ) trended earlier, particularly in Jokioinen and Laukaa (Table 6). The location of Ruukki near the coast explains the lack of late frosts there. There were no negative yield impacts due to late frosts for the mean annual yields of the experimental sites nor for the annual mean regional farmers' yields. (Table 6). Harvest conditions and lodging effects, analysed by calculating precipitation sums and maximum daily precipitations around harvest and maturity, did not show any clear trends over the $42 \mathrm{yr}$ period. In addition, there were no significant yield impacts due to these variables at experimental sites or in farmers' fields (Table 6).

\subsubsection{Changes in soil types where barley is grown}

The soil types where barley was grown did not change notably during the $21 \mathrm{yr}$ study period (see 


\section{Potential yield}
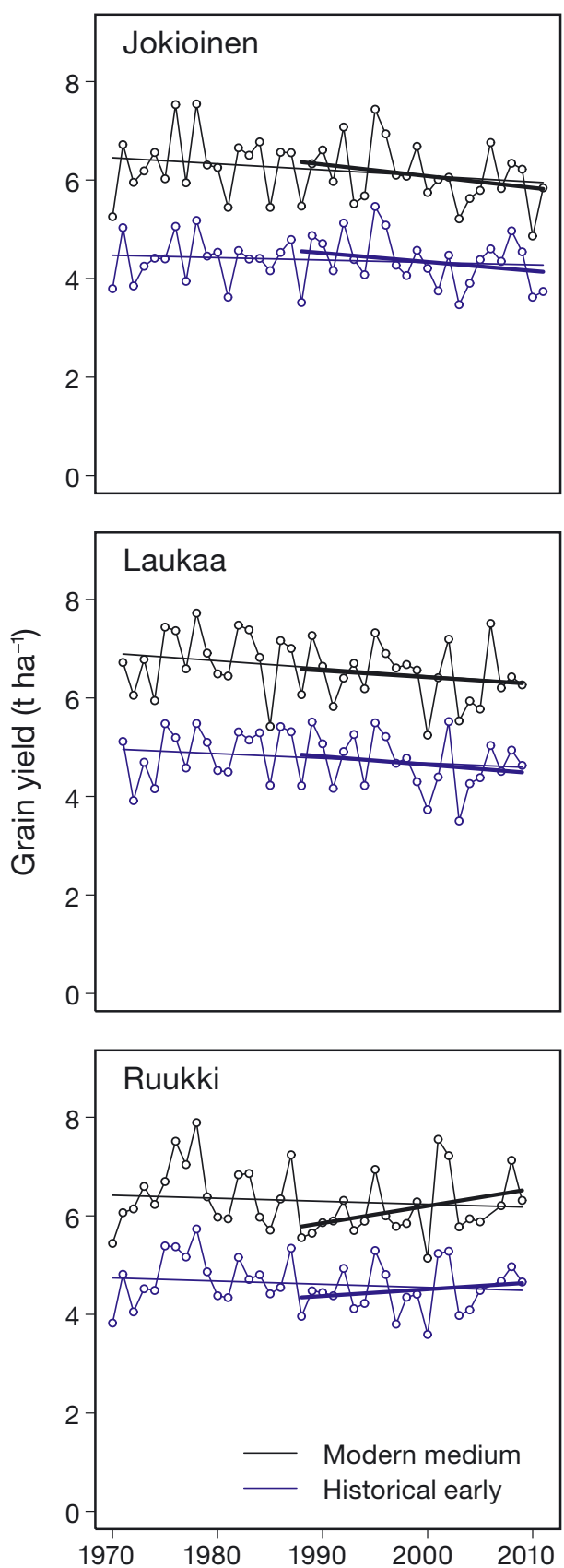

WL yield, clay soil
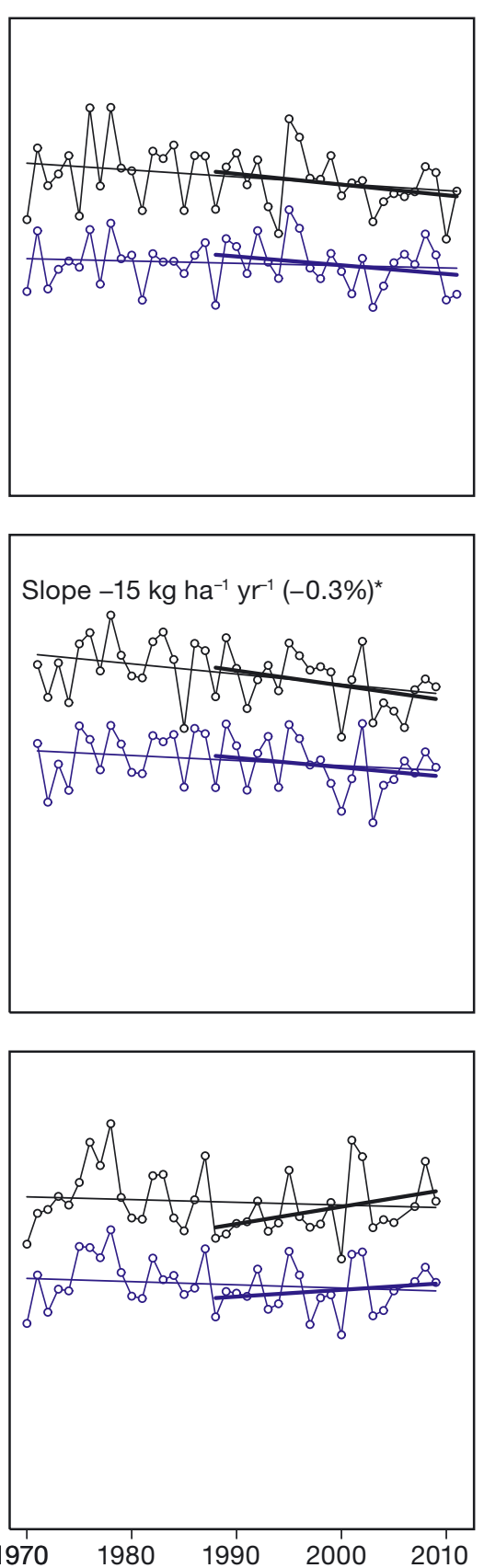

WL yield, coarse sandy soil
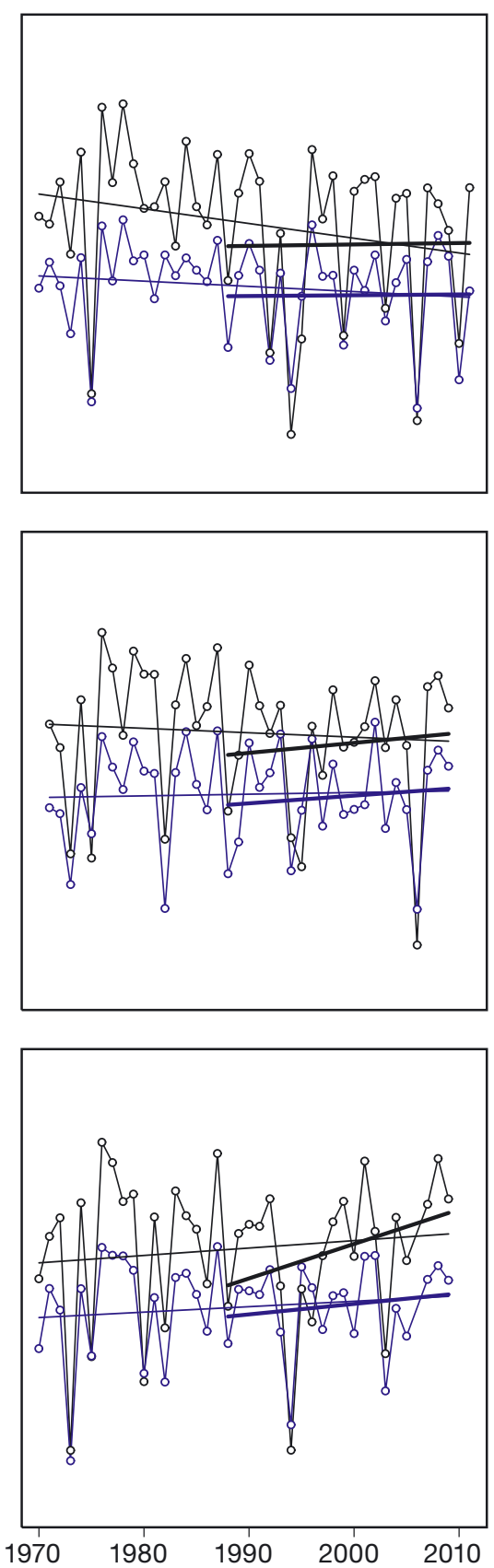

Fig. 3. Simulated grain yields (dry matter) time series, potential (left column) and water-limited (WL) for clay and coarse sandy soil at the 3 study sites (middle and right columns) for the (blue) historical early and (black) modern intermediate barley Hordeum vulgare L. cultivar classes (Table 2). The thin lines are trend lines for the longer time series and the thick lines are for the shorter time series comparable to the observed time series of farmers. The only trend line with a slope with $\mathrm{p}<0.01$ (modern medium cultivar at Laukaa) is marked in the figure

Fig. S2 in the Supplement at www.int-res.com/ articles/suppl/c065p221_supp.pdf). There seems to have been a decrease in the proportion of clay soils in the Central Finland region, but the amount of missing data there has also increased over the last few years.

\subsection{Cultivar effects on yield trends}

During the $21 \mathrm{yr}$ study period, the cultivar sets used by farmers have changed completely (Fig. 4). Cultivars that were introduced in variety trials prior to 1991 were almost completely abandoned by 2008 . 
Table 6. Last date of frost, precipitation sum and maximum precipitation around harvests at the 3 study sites from 1970 to 2011. Trends and impact estimated with linear regression. ${ }^{*} \mathrm{p}<0.05,{ }^{* *} \mathrm{p}<0.01,{ }^{* * *} \mathrm{p}<0.001$

\begin{tabular}{|c|c|c|c|}
\hline & Jokioinen & Laukaa & Ruukki \\
\hline \multicolumn{4}{|l|}{ Last date of frost } \\
\hline Mean (day of the year) & 145 & 148 & 137 \\
\hline Trend $\left(\mathrm{d}\right.$ decade $\left.{ }^{-1}\right)$ & $-4^{* *}$ & $-5^{* * *}$ & -1 \\
\hline Yield impact, farmers' $\left(\mathrm{kg} \mathrm{ha}^{-1} \mathrm{~d}^{-1}\right)$ & 1 & 0 & $25^{*}$ \\
\hline Yield impact, trials $\left(\mathrm{kg} \mathrm{ha}^{-1} \mathrm{~d}^{-1}\right)$ & 7 & 70 & 68 \\
\hline \multicolumn{4}{|c|}{ Precipitation sum -5 to $+10 \mathrm{~d}$ either side of maturity } \\
\hline \multicolumn{4}{|c|}{ Historical early } \\
\hline Mean (mm) & 57 & 51 & 40 \\
\hline Trend (mm decade ${ }^{-1}$ ) & 0 & -8 & 0 \\
\hline Yield impact, farmers' $\left(\mathrm{kg} \mathrm{ha}^{-1} \mathrm{~mm}^{-1}\right)$ & 1 & -1 & -5 \\
\hline Yield impact, trials $\left(\mathrm{kg} \mathrm{ha}^{-1} \mathrm{~mm}^{-1}\right)$ & -13 & 2 & 2 \\
\hline \multicolumn{4}{|l|}{ Modern late } \\
\hline Mean (mm) & 48 & 39 & 33 \\
\hline Trend $\left(\mathrm{mm}\right.$ decade $\left.{ }^{-1}\right)$ & -4 & -3 & -3 \\
\hline Yield impact, farmers' $\left(\mathrm{kg} \mathrm{ha}^{-1} \mathrm{~mm}^{-1}\right)$ & -3 & -2 & 0 \\
\hline Yield impact, trials $\left(\mathrm{kg} \mathrm{ha}^{-1} \mathrm{~mm}^{-1}\right)$ & -1 & 0 & 1 \\
\hline \multicolumn{4}{|c|}{ Maximum daily precipitation -10 to $+10 \mathrm{~d}$ either side of maturity $(\mathrm{mm})$} \\
\hline \multicolumn{4}{|c|}{ Historical early } \\
\hline Mean (mm) & 20 & 18 & 14 \\
\hline Trend & 1 & -3 & 0 \\
\hline Yield impact, farmers' $\left(\mathrm{kg} \mathrm{ha}^{-1} \mathrm{~mm}^{-1}\right)$ & 7 & -5 & -13 \\
\hline Yield impact, trials $\left(\mathrm{kg} \mathrm{ha}^{-1} \mathrm{~mm}^{-1}\right)$ & -19 & -10 & 18 \\
\hline \multicolumn{4}{|l|}{ Modern late } \\
\hline Mean (mm) & 17 & 16 & 13 \\
\hline Trend & -1 & $-3^{*}$ & 0 \\
\hline Yield impact, farmers' $\left(\mathrm{kg} \mathrm{ha}^{-1} \mathrm{~mm}^{-1}\right)$ & 9 & -2 & 19 \\
\hline Yield impact, trials $\left(\mathrm{kg} \mathrm{ha}^{-1} \mathrm{~mm}^{-1}\right)$ & -2 & 35 & 58 \\
\hline
\end{tabular}

The shift towards newer cultivars was somewhat faster in the Häme region than in Central Finland or North Ostrobothnia. The use of late-maturing cultivars decreased the further north the sites were located.

It can be seen that the yield potential, as reported in official variety trial data (Kangas et al. 2010), of the cultivars most used by farmers clearly increased. In general, the modern cultivars exhibit shorter straw, and improved lodging and $\mathrm{N}$-use efficiency traits in comparison to historical cultivars (see Table S1 in the Supplement).

Yield levels simulated for different cultivar types in the representative soil types at Jokioinen, Laukaa and Ruukki varied greatly (Fig. 5). The mean simulated yield - weighted based on the cultivar use of the farmers in the regions (from Fig. 4)-clearly increased at all sites. As the mean annual yield trend of simulated yields of individual cultivar types in the 2 extreme soils varied from negative to slightly posi- tive at all 3 sites (Table 4 ), the shifts in cultivar use made the trends clearly more positive.

\subsection{Agro-management effects on yield trends}

\subsubsection{Sowing dates}

Farmers' sowing dates advanced during the studied period from 1988 to 2008 in all the studied regions, despite the fact that the interannual variability in sowing dates is still great (see Fig. S3 in the Supplement at www.int-res.com/articles/suppl/ c065p221_supp.pdf). In the Häme region and Central Finland, the sowing dates advanced by about $4 \mathrm{~d}$ per decade, and by about $1 \mathrm{~d}$ per decade in North Ostrobothnia. However, these changes had only a small overall effect on simulated yields. The simulated effect of the shift in sowing dates on yields was small and not statistically significant (Table 4) when comparing the simulated yields with sowing dates (from a trend line in Fig. S3) from 1988 and 2008.

\subsubsection{Fertiliser use}

The amounts of both $\mathrm{N}$ and $\mathrm{P}$ fertiliser applied by farmers decreased in all 3 regions, though there was high variation between fields. Nitrogen application rates decreased moderately, by $\sim 2 \mathrm{~kg} \mathrm{ha}^{-1}$ per decade in Häme and $\sim 10 \mathrm{~kg} \mathrm{ha}^{-1}$ per decade in the other 2 regions (Fig. 6a).

The decreases in $\mathrm{P}$ fertilisation rates were steeper than those of N. The decreases in Häme, Central Finland and North Ostrobothnia were, on average, from 23,26 and $32 \mathrm{~kg} \mathrm{ha}^{-1}$ to 12,12 and $10 \mathrm{~kg} \mathrm{ha}^{-1}$, respectively (Fig. 6b), for the period 1988 to 2008 .

Yield levels that were estimated to be possible with the provided $\mathrm{N}$ and $\mathrm{P}$ fertiliser amounts applied decreased slightly during the period from 1990 to 2008 (Fig. 7). The slight decrease in N uptake from soil reserves did not change the trends significantly, whereas the differences in $\mathrm{P}$ uptake from soil reserves had quite a large effect on P-limited yield 


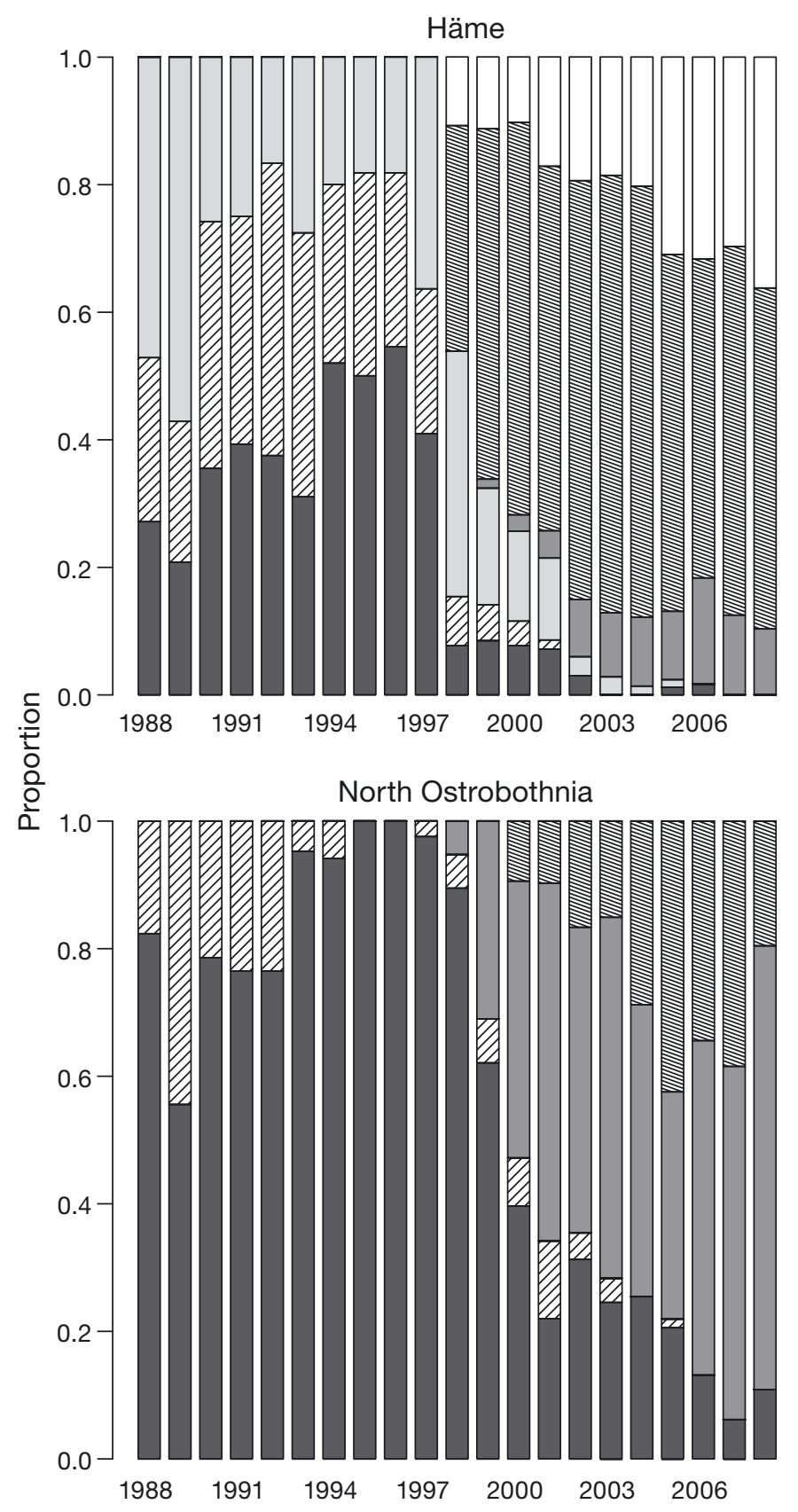

levels. The P uptake from soil reserves in the study regions was so high that the P-limited yield was mostly higher than water-limited simulated yields, particularly in Häme and North Ostrobothnia. Nitrogen availability limited the yields in most years in all 3 study regions.

\subsection{Yield gaps}

The yield gap between the simulated water-limited yields and farmers' yields in Häme, which is an im-

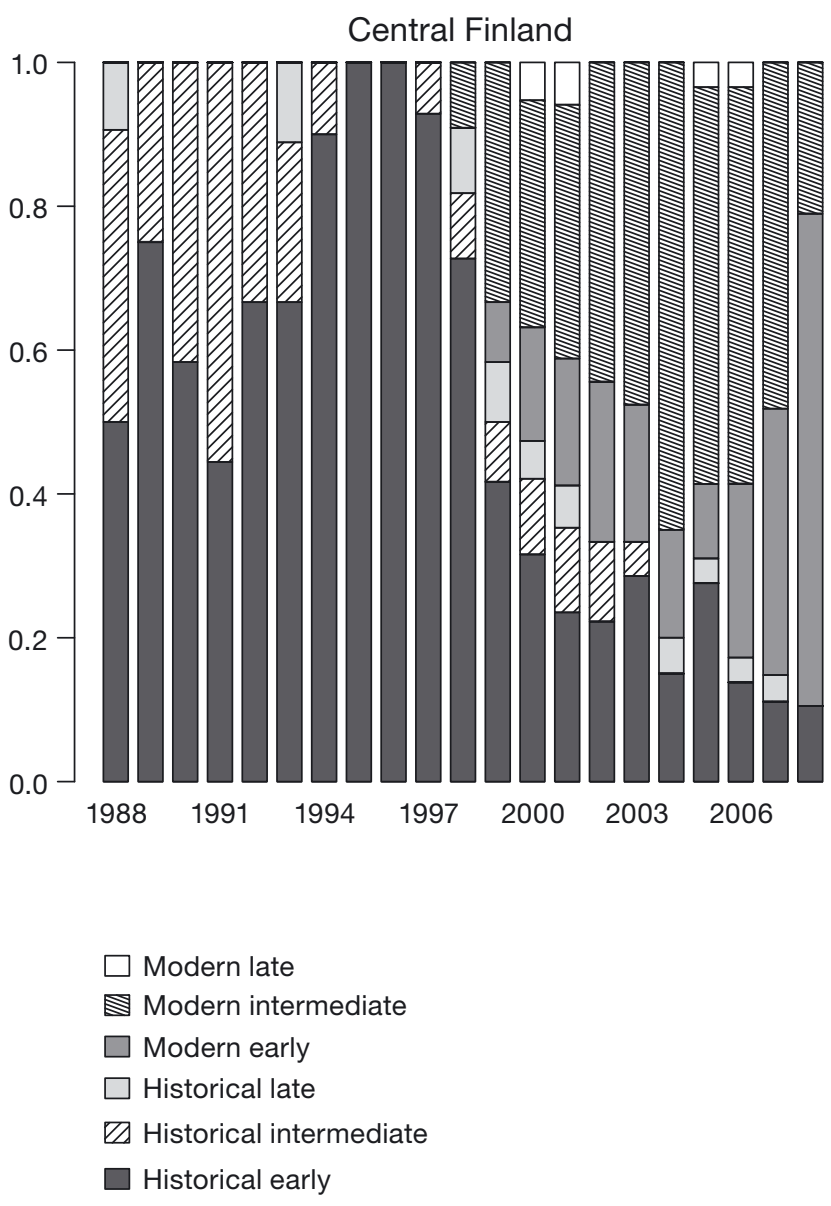

Fig. 4. Farmers' barley Hordeum vulgare L. cultivar use in the 3 study regions. Cultivars are presented in 6 classes according to their phenology (early, late intermediate - earliest and latest quartiles and the remainder, respectively) and time of appearance (historical, modern). Historical cultivars are those introduced to variety trials prior to 1990 and the rest were classified as 'modern' cultivars

portant cereal production area in Finland, increased from $1.5 \mathrm{t} \mathrm{ha}^{-1}$ in 1988 to $2.4 \mathrm{t} \mathrm{ha}^{-1}$ in 2008 (Fig. 8). The gap in North Ostrobothnia increased slightly from 1.7 to $2.1 \mathrm{t} \mathrm{ha}^{-1}$. In Central Finland, the yield gap decreased from 2.4 to $2.2 \mathrm{t} \mathrm{ha}^{-1}$. The gap between the simulated potential and water-limited yields in these representative soil types acted differently in different regions. The gap decreased in Häme from 0.6 to $0.3 \mathrm{t} \mathrm{ha}^{-1}$, and increased in Central Finland from $0.1 \mathrm{t} \mathrm{ha}^{-1}$ in 1988 to $0.6 \mathrm{t} \mathrm{ha}^{-1}$ in 2008 . In North Ostrobothnia, it remained very small and decreased from 0.05 to $0.02 \mathrm{t} \mathrm{ha}^{-1}$ (Fig. 8). 

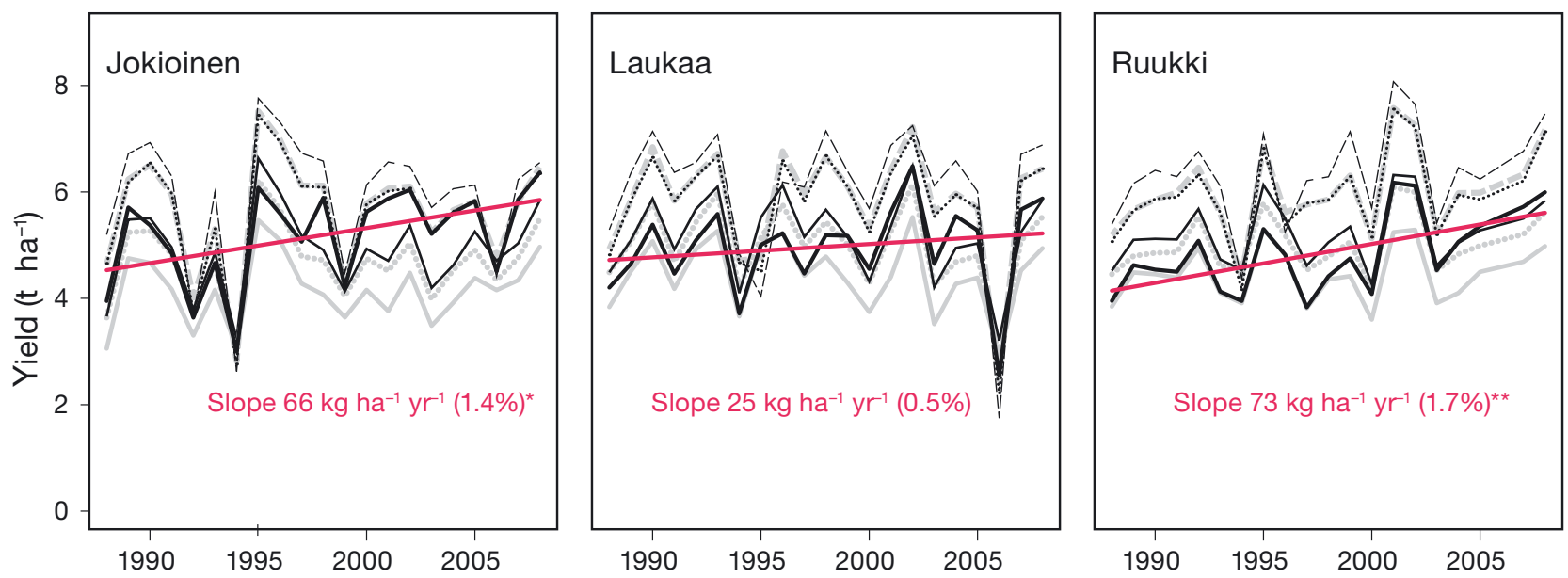

Fig. 5. Simulated water-limited dry matter yields of different barley Hordeum vulgare L. cultivar types from 1988 to 2008 at the 3 experimental sites with different soil types. Thin black lines: modern cultivars; thick grey lines: historical cultivars. Solid, dotted and dashed lines: early, intermediate and late cultivar groups, respectively. Thick black lines: mean yield weighted with the farmers' cultivar use of the region (presented in Fig. 4); pink line: trend line. ${ }^{*} p<0.05,{ }^{* *} p<0.01 ; p>0.05$ is not indicated
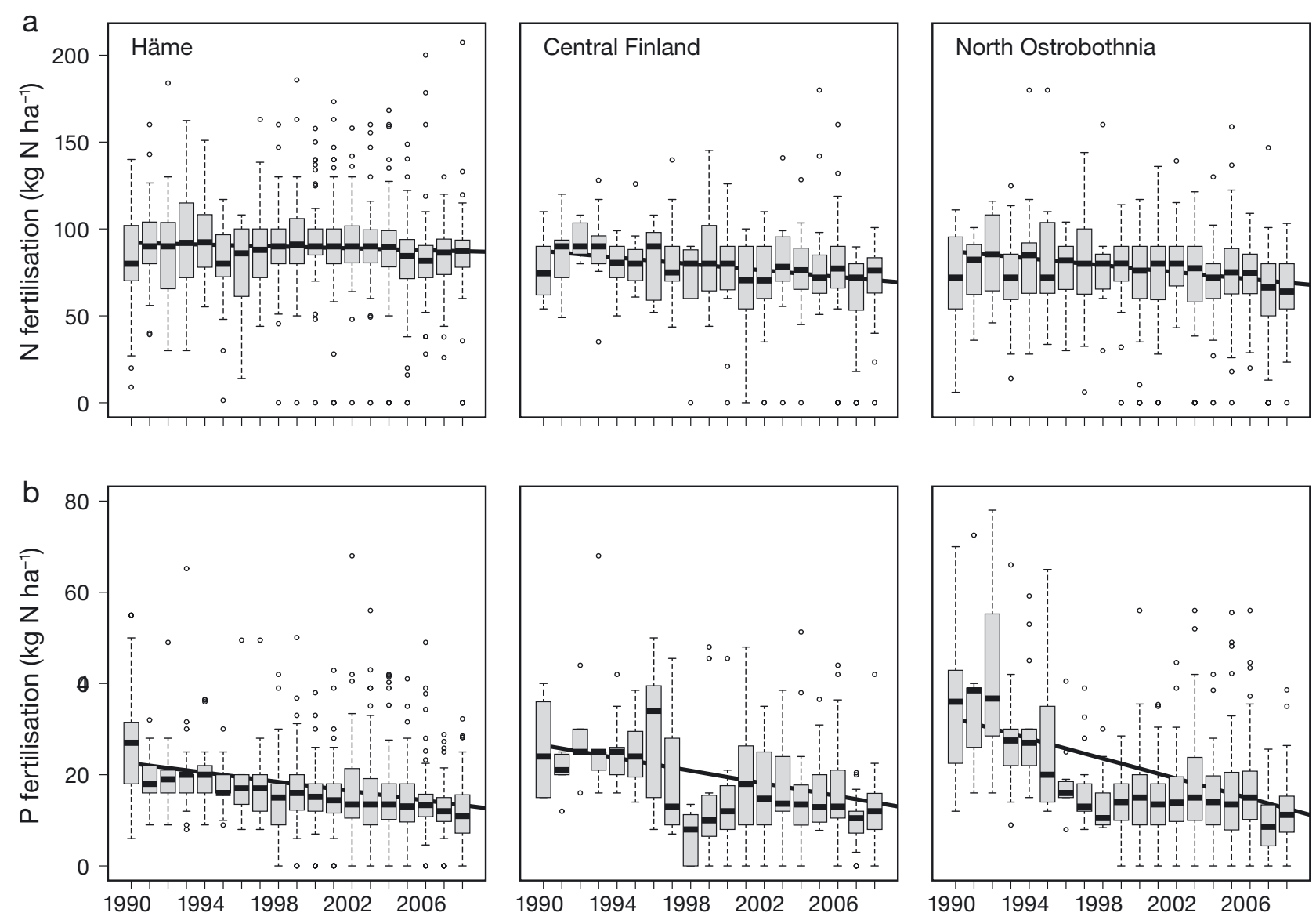

Fig. 6. Levels of (a) N and (b) P fertiliser $\left(\mathrm{kg} \mathrm{ha}^{-1}\right)$ applied (including manure considered as inorganic N) by farmers from 1988 to 2008 for the barley Hordeum vulgare L. cultivated in the 3 ELY Centre regions. Boxes indicate the lower and upper quartiles. The solid line within the box is the median. Whiskers indicate the most extreme data point, which is no more than 1.5 times the interquartile range from the box, and the outlier dots are those observations that go beyond that range 

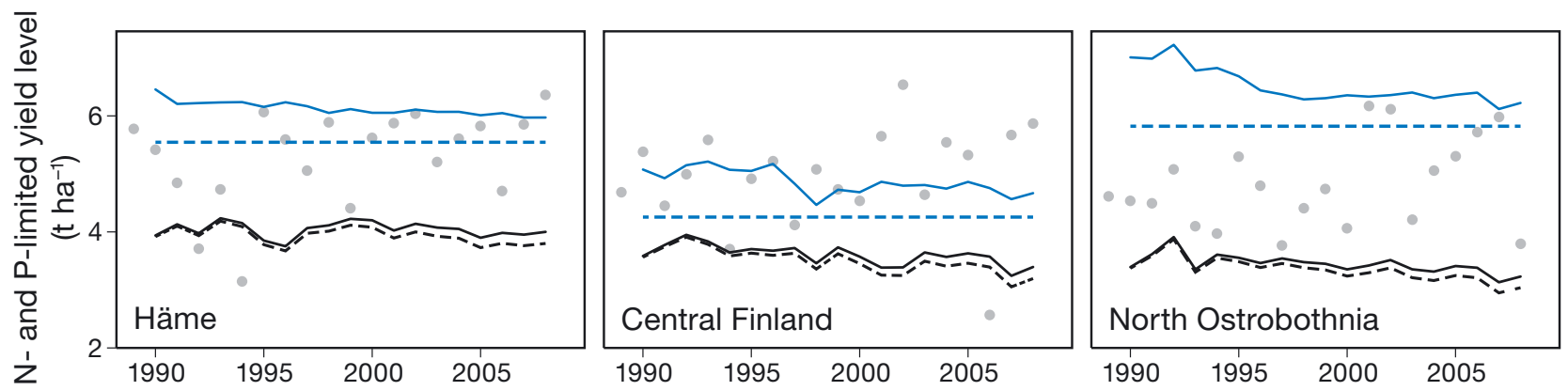

Fig. 7. Barley Hordeum vulgare L. yield levels (dry weight) estimated based on uptakes of available macronutrients $\mathrm{N}$ and $\mathrm{P}$ from fertilisers and soil reserves. N-limited yield estimate with (solid black line) stable and (dashed black line) decreasing uptake from soil reserves. P-limited yield estimates take into account both (solid blue line) uptake from soil reserves and fertiliser amounts and (dashed blue line) uptake from soil reserves only. (Grey dots) Cultivar-type weighted simulated water-limited yields (from Fig. 5)
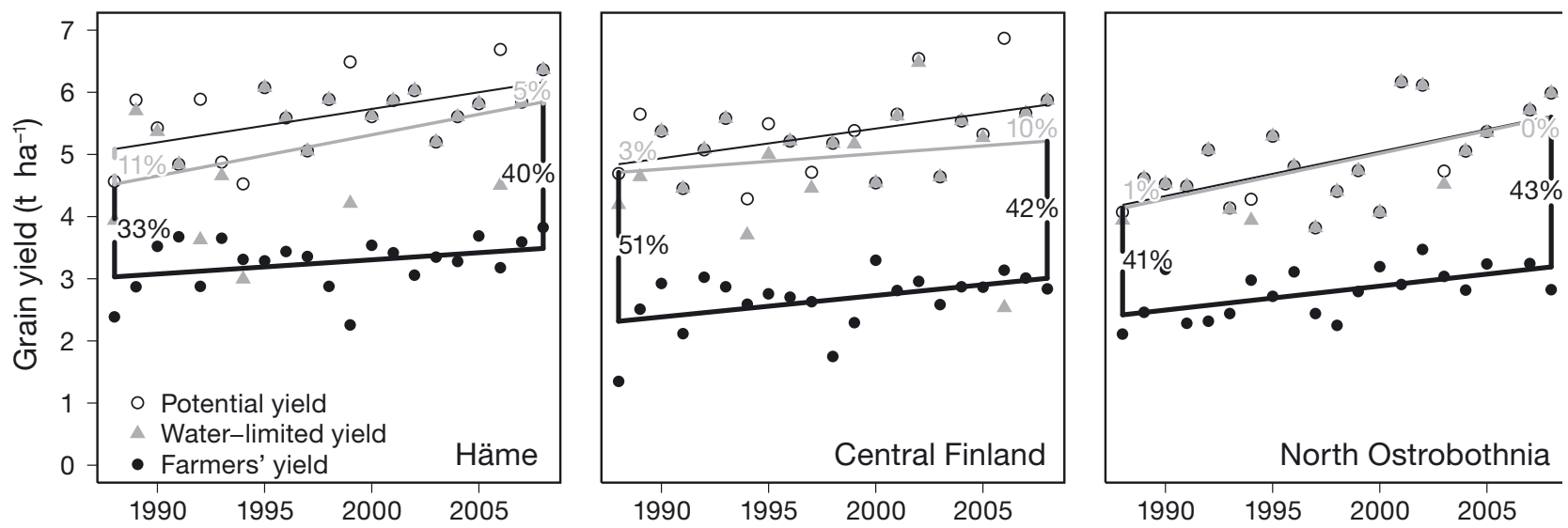

Fig. 8. Yield gaps in the 3 study regions, illustrated for barley Hordeum vulgare L. yields (dry weight). O with black thin trend line: simulated potential yields; $\Delta$ with grey trend line: simulated water-limited yields; $\mathbf{c}$ with thick black trend line: observed farmers' yields. Percentages and vertical lines illustrate the yield gap at the first and last years of the time series

\section{DISCUSSION}

\subsection{Both yields and yield gaps have been increasing}

Observed yield trends in this study showed that farmers' yields have been increasing during the past $20 \mathrm{yr}$ and the increasing trend has been stronger in northern than in southern Finland (Fig. 2). At the same time, yield gaps between the simulated waterlimited yields (calculated for the cultivar types used by farmers) and barley yields reported by farmers have been increasing in Häme, one of the two main barley cultivation regions in Finland (Fig. 1), and in North Ostrobothnia (Fig. 8). The yield gaps indicated by the differences between the observed yields of experimental sites and other farms have also been increasing (Fig. 2). This most likely reflects the better and more consistent management at the experimental sites, including crop rotation, than that exhibited by the majority of farmers. Similar results have been obtained in other Nordic countries (e.g. Denmark and Sweden) and reported at seminars (www.cernet. $\mathrm{dk} /$ ), although to our knowledge, no studies directly focused on this difference have yet been published.

\subsection{Cultivar effects on yield trends}

According to our analysis, the positive trends have mostly resulted from the development and usage of new, high-yielding barley cultivars. This is clearly in line with previous studies from Finland (PeltonenSainio et al. 2009c) as well as with the general trend in the development of new high-yielding genotypes for cereals and other crops (Brisson et al. 2010). However, as demonstrated by the differences between the yield levels of variety trials and farmers of surrounding regions (Fig. 2), for example, it seems that there is still a significant unexploited potential for 
boosting yields. This could possibly be utilised by more rapid introduction of the latest cultivars with adequate management, including the use of commercially certified seeds by farmers. Currently, the majority of farmers (between 50 and $80 \%$, depending on year and cultivation purpose) in Finland use farmsaved seeds for all cereals. Farmers' adoption of new cultivars is relatively slow (Peltonen-Sainio \& Rajala 2014).

\subsection{Agro-management effects on yield trends}

Large changes in market and policy drivers that affected the agro-management practices of farmers occurred in Finland during the study period. In 1995, when Finland joined the European Union, crop prices decreased by 40 to $60 \%$ and fertiliser prices by approximately $10 \%$, and a large scale Agri-Environment Programme (AEP) was launched. Lehtonen et al. (2007), however, concluded that the major price changes experienced in Finland after 1995 resulted in total reductions in cereal yields of no more than $5 \%$, due to the short-term farm-level profit maximisation based on variable costs and returns. The AEP provided a stable €93-120 per ha support payment, on the top of Common Agricultural Policy (CAP) Pillar 1 (€150-240 per ha, depending on region) and Least Favourable Area (LFA) payments (averaging $€ 250$ per ha), for those farmers who committed to comply with the $\mathrm{N}$ fertiliser limits and other conditions of the AEP. Farmers have been highly committed to the AEP, which is rational from a risk aversion point of view, considering the volatile crop and fertiliser prices since 2007 and the cost minimisation tendency of small and inefficient farms, which are implicitly incentivised by CAP area payments and high production costs (Lehtonen \& Rankinen 2015).

Due to the introduction of the above-mentioned support programmes in 1995, as well as their in-built incentives for extensive production, the area under cereals increased by almost $20 \%$ between 1995 and 2002 (Matilda Agricultural Statistics 2014), as grassland and set-aside received lower support payments than cereals. Despite the CAP Fischler reform in 2006 (which led to almost equal support payments for grasslands and set-aside), the cereal area has stabilised at 1.0 to 1.2 million hectares. It is likely that the cereal area also expanded to fields and soils that were less suitable for cereal production than fields where cereals had previously been cultivated. All the above-mentioned policy drivers and associated land use changes, as well as the increased land tenure and tenure insecurity due to short tenure contracts, have thus led to less intensive crop and soil management, as reflected in Fig. S4 (in the Supplement at www.intres.com/articles/suppl/c065p221_supp.pdf), and a reduction in the positive trends in farmers' yields. In particular, Myyrä et al. (2005) found that the drivers decreasing the expected profitability of medium and long-term investments in soil fertility have probably affected liming and drainage investments in Finland. Liming activity has not completely ceased, but it has decreased to approximately half of the necessary amount for stabilising the soil pH (see Fig. S4). Decreased $\mathrm{N}$ fertilisation and liming alone, due to discouraging markets and policies, may have resulted in a 5 to $10 \%$ reduction in cereal crop yields in $20 \mathrm{yr}$. Similar results have been obtained from recent dynamic farm-level economic modelling (X. Liu et al. unpubl.), where $\mathrm{N}$ fertilisation and liming decisions are accounted for in economic farm management decisions.

There is evidence that the frequency of barley fields being infected by pathogens has significantly increased during the past $40 \mathrm{yr}$ in Finland (M. Jalli pers. comm. 22 April 2015). This has been explained by the high proportion of barley, which limits the possibility for crop rotation, and also by the increased use of reduced or no-till. Fungicide usage in Finland remains low compared to other European countries (Heinonen et al. 2013). However, a significant improvement in the level of net blotch resistance has been found in the European barley cultivars released during the last 40 yr (Jalli 2011). Net blotch is the most common plant disease found in barley in Finland. The total abundance of weeds has remained the same in recent decades in conventional cropping, whereas an increase in total biomass of weeds has been associated with organic cropping (Salonen et al. 2013).

\subsection{Environmental effects on yield trends}

According to our simulations, the climate effects on yields have been 2 -fold. While growing seasons in Finland have been getting longer (Peltonen-Sainio \& Jauhiainen 2014), which supports the usage of latermaturing, high-yielding cultivars, the simulated potential yields of individual cultivars have been decreasing at all the 3 study sites (Fig. 3). This is mainly because the slightly increased summer temperatures (Table 1) have shortened the grain-filling period. These simulations, however, did not take into account the direct effects of changes in $\mathrm{CO}_{2}$ levels on crop growth. Overall, however, the annual mean 
atmospheric $\mathrm{CO}_{2}$ level has increased during the $40 \mathrm{yr}$ simulation period, from 326 to $390 \mathrm{ppm}(20 \%)$ (NOAA Research 2014). If this increase had been taken into account, the trends of potential yields would have increased slightly (by about 3 to $5 \%$ ), but would not have been sufficient to turn them positive $\left(\mathrm{CO}_{2}\right.$ effect estimated based on Tubiello et al. 2007). The trends of water-limited yields depend both on the trends in rainfall and on the soil type, which affect the amount of plant-available water in the soil. According to our simulation results, drought effects on yields have not changed significantly at any of the study sites (Fig. 3, Table 4).

Other weather patterns studied were not found to affect observed yields. The dates of last occurrence of frost have advanced, particularly in Central Finland (Table 6). van Oort et al. (2012) found that the 2 most important climate extremes affecting potato production in the Netherlands were a wet start and a wet end to the growing season. In this study, no connection was found between harvest conditions and reported yields (Table 6).

\subsection{Uncertainties in simulation results and the empirical database}

In this study, crop model simulation results were used both to indicate potential yields and to separate the effects of changes in different yield-determining factors. Crop simulation models are widely and increasingly used for this purpose, i.e. in yield gap analysis (van Ittersum et al. 2013), and in analysing the contribution of historical adaptation to yield trends (e.g. Sacks \& Kucharik 2011). In recent blind tests of model intercomparisons for winter wheat (Palosuo et al. 2011) and spring barley (Rötter et al. 2012), model uncertainty was considerable. However, comparisons of well-calibrated crop models with yields observed at well-managed experimental sites generally show satisfactory agreement-at least for potential and water-limited production situations (see e.g. Song et al. 2006).

In this study, crop model simulations were initiated separately for each simulation year, and this was done by assuming constant soil water conditions. However, soil hydrological conditions vary with the weather and can be modified by changes in agromanagement with long-term effects on yields. For example, changes in drainage are of particular importance in Finnish conditions. There have also been changes in other soil properties of Finnish agricultural soils during the study period, such as the declin- ing trend in soil organic carbon (Heikkinen et al. 2013), which may be due to relatively late land conversion from forest to cropland (Akujärvi et al. 2014) and intensification of soil management due to advanced machinery. In addition, changes in crop rotations were not taken into account within this study, although crops grown in short rotations reportedly have lower yields for a variety of reasons (Bennett et al. 2012).

Generally, variety trial data is considered to be very reliable with standardised protocols. The average coefficient of variation reported by Taylor et al. (1999), based on 142 wheat variety trials, was $14 \%$. Yield estimates by farmers are most likely to be less accurate. The smaller interannual variation in farmers' yields also reflects the conservativeness of these estimates: they may overestimate low yields and underestimate high yields.

\subsection{Perspectives on climate change adaptation}

Our results further highlight the importance of active development of robust and locally adapted cultivars for northern conditions. The cultivar shifts in the past several decades, which were characterised by more frequent use of late-maturing varieties (with use decreasing the further north the site was located), contributed markedly to annual overall yield growth rates of 0.5 to $1.4 \%$ (Fig. 5). Since breeding high-yielding and climate-resilient new cultivars has recently received considerable attention worldwide (e.g. Tester \& Langridge 2010), it can be expected that further cultivar shifts will take place and contribute to yield increases in the future. In addition, it is important to exploit the diversity of cultivars for a given region in order to maintain resilience to varying future conditions (Kahiluoto et al. 2014). However, several studies suggest that breeding alone most likely cannot compensate for the yield declines in all soil types if the most extreme climate scenarios materialise (e.g. Rötter et al. 2011). Improvements in soil $\mathrm{pH}$ and drainage, subject to sufficient market and policy incentives, may become more important in extreme conditions, even though they are not sufficient for compensating for yield losses. Market prices essentially drive crop rotations (which affect soil structure and also plant disease pressure) and long-term management decisions (X. Liu et al. unpubl.). Market and policy incentives are especially important in the Nordic context, where the number of feasible and marketable crops is limited, and where production costs are high. 


\section{CONCLUSIONS}

Plant breeding progress through the introduction of new cultivars has been the primary driver of increasing barley yields in Finland. While warmer growing conditions have negatively impacted the yield growth rates of individual cultivars, adaptation through the use of cultivars that are more suited to warmer conditions has co-determined gradual barley yield increases. This is despite market and policy conditions that have led to slightly reduced nitrogen and phosphorus fertiliser application and more extensive cultivation. However, the positive trend of barley yield growth rates has levelled off in recent years. During the past $20 \mathrm{yr}$, management practices for high yields has been discouraged by prevailing market and policy conditions, such as volatile prices and fertiliser limitations of the AEP programme. Another driver for the levelling out of yield growth rates is the expansion of the barley production area to less suitable soils.

Soil hydrological conditions affected by agro-management, such as drainage and liming, as well as narrow or absent crop rotations, may have long-term effects on yields, as well as a gradually declining trend in soil organic carbon. Substantial breeding efforts aimed at climate-robust cultivars (Rötter et al. 2015), longer and more diverse crop rotations, and increased liming and drainage investments are likely to be increasingly necessary in the future to maintain and increase barley yields. Their realisation, however, requires stimulation by future market prices and enabling policies.

Acknowledgements. Thanks to Lauri Jauhiainen, Ari Rajala and Marja Jalli for their help in gathering cultivar data. This work was conducted as part of the following research projects: Finnish Research Programme on Climate Change's (FICCA) A-LA-CARTE project (decision no. 140806), funded by the Academy of Finland; NORFASYS (decision no. 268277) project, also funded by the Academy of Finland; FACCE-Macsur, funded by the Finnish Ministry of Agriculture and Forestry; ILMAPUSKURI, funded by the Finnish Ministry of Agriculture and Forestry and MTT Agrifood Research Finland; and MODAGS and SusIntens, funded by MTT Agrifood Research Finland.

\section{LITERATURE CITED}

Akujärvi A, Heikkinen J, Palosuo T, Liski J (2014) Carbon budget of Finnish croplands - effects of land use change from natural forest to cropland. Geoderma Reg 2-3:1-8

$>$ Bennett AJ, Bending GD, Chandler D, Hilton S, Mills P (2012) Meeting the demand for crop production: the challenge of yield decline in crops grown in short rota- tions. Biol Rev Camb Philos Soc 87:52-71

> Bindi M, Olesen JE (2011) The responses of agriculture in Europe to climate change. Reg Environ Change 11: 151-158

Boogaard HL, van Diepen CA, Rötter RP, Cabrera JMCA, van Laar HH (1998) WOFOST 7.1. User's guide for the WOFOST 7.1 crop growth simulation model and WOFOST Control Center 1.5. 52, DLO Winand Staring Centre, Wageningen

Boons-Prins ER, De Koning GHJ, van Diepen CA, de Vries FWTP (1993) Crop specific simulation parameters for yield forecasting across the European Community. CABO-DLO, Wageningen

Brisson N, Gate P, Gouache D, Charmet G, Oury F, Huard F (2010) Why are wheat yields stagnating in Europe? A comprehensive data analysis for France. Field Crops Res 119:201-212

Carter TR, Saarikko R (1996) Estimating regional crop potential in Finland under a changing climate. Agric For Meteorol 79:301-313

Evans LT, Fischer RA (1999) Yield potential: its definition, measurement, and significance. Crop Sci 39:1544-1551

Evira (2012) Finnish grain quality in 2011. Evira publications 6/2012, Finnish Food Safety Authority Evira, Helsinki

Hakala K, Jauhiainen L, Himanen S, Rötter R, Salo T, Kahiluoto H (2012) Sensitivity of barley varieties to weather in Finland. J Agric Sci 150:145-160

Heikkinen J, Ketoja E, Nuutinen V, Regina K (2013) Declining trend of carbon in Finnish cropland soils in 19742009. Glob Chang Biol 19:1456-1469

Heinonen U, Jalli M, Junnila S, Mäkinen T (2013) The management of fungicide resistance in cereals in Finland. MTT Report 109, MTT Agrifood Research Finland, Jokioinen. www.mtt.fi/mttraportti/pdf/mttraportti109.pdf

IPCC (2013) Climate change 2013: the physical science basis. In: Stocker TF, Qin D, Plattner GK, Tignor M and others (eds) Contribution of Working Group I to the Fifth Assessment Report of the Intergovernmental Panel on Climate Change. Cambridge University Press, New York, NY

Jalli M (2011) Sexual reproduction and soil tillage effects on virulence of Pyrenophora teres in Finland. Ann Appl Biol 158:95-105

Janssen B, Guiking F, Van der Eijk D, Smaling E, Wolf J, Van Reuler H (1990) A system for quantitative evaluation of the fertility of tropical soils (QUEFTS). Geoderma 46: 299-318

Kahiluoto H, Kaseva J, Hakala K, Himanen SJ and others (2014) Cultivating resilience by empirically revealing response diversity. Glob Environ Change 25:186-193

Kangas A, Laine A, Niskanen M, Salo Y, Vuorinen M, Jauhiainen L, Nikander H (2010). Results of official variety trials. MTT Agrifood Research Finland, Jokioinen (in Finnish)

> Kaukoranta T, Hakala K (2008) Impact of spring warming on sowing times of cereal, potato and sugar beet in Finland. Agric Food Sci 17:165-176

> Lehtonen H, Rankinen K (2015) Impacts of agri-environmental policy on land use and nitrogen leaching in Finland. Environ Sci Policy 50:130-144

> Lehtonen H, Lankoski J, Koikkalainen K (2007) Economic and environmental performance of alternative policy measures to reduce nutrient surpluses in Finnish agriculture. Agric Food Sci 16:421-440

Lehtonen I, Ruosteenoja K, Jylhä K (2014) Projected changes 
in European extreme precipitation indices on the basis of global and regional climate model ensembles. Int J Climatol 34:1208-1222

Lindén B, Lyngstad I, Sippola J, Soegaard K, Kjellerup V (1992) Nitrogen mineralization during the growing season. 1. Contribution to the nitrogen supply of spring barley. Swed J Agric Res 22:3-12

Matilda Agricultural Statistics (2014) Agricultural Statistics. Natural Resources Institute Finland (Luke) http://stat. luke.fi/en/maatalous

Muurinen S, Kleemola J, Peltonen-Sainio P (2007) Accumulation and translocation of nitrogen in spring cereal cultivars differing in nitrogen use efficiency. Agron J 99:441-449

Myyrä S, Ketoja E, Yli-Halla M, Pietola K (2005) Land improvements under land tenure insecurity: the case of $\mathrm{pH}$ and phosphate in Finland. Land Econ 81:557-569

NOAA Research (2014) The table of annual mean carbon dioxide growth rates for Mauna Loa. Global Monitoring Division, Earth System Research Laboratory, NOAA Research, U.S. Dept of Commerce, Boulder, CO. www. esrl.noaa.gov/gmd/ccgg/trends/ (Accessed 15 December 2014)

> Olesen J, Trnka M, Kersebaum K, Skjelvåg AO and others (2011) Impacts and adaptation of European crop production systems to climate change. Eur J Agron 34:96-112

Palosuo T, Kersebaum KC, Angulo C, Hlavinka P and others (2011) Simulation of winter wheat yield and its variability in different climates of Europe: a comparison of eight crop growth models. Eur J Agron 35:103-114

Pathak H, Aggarwal PK, Rötter RP, Kalra N, Bandyopadhaya SK, Prasad S, Van Keulen H (2003) Modelling the quantitative evaluation of soil nutrient supply, nutrient use efficiency, and fertilizer requirements of wheat in India. Nutr Cycl Agroecosyst 65:105-113

Peltonen-Sainio P, Jauhiainen L (2014) Lessons from the past in weather variability: sowing to ripening dynamics and yield penalties for northern agriculture from 1970 to 2012. Reg Environ Change 14:1505-1516

Peltonen-Sainio P, Rajala A (2014) Use of quality seed as a means to sustainably intensify northern European barley production. J Agric Sci 152:93-103

Peltonen-Sainio P, Muurinen S, Rajala A, Jauhiainen L (2008) Variation in harvest index of modern spring barley, oat and wheat cultivars adapted to northern growing conditions. J Agric Sci 146:35-47

> Peltonen-Sainio P, Jauhiainen L, Hakala K (2009a) Are there indications of climate change induced increases in variability of major field crops in the northernmost European conditions? Agric Food Sci 18:206-222

Peltonen-Sainio P, Jauhiainen L, Hakala K, Ojanen H (2009b) Climate change and prolongation of growing season: changes in regional potential for field crop production in Finland. Agric Food Sci 18:171-190

Peltonen-Sainio P, Jauhiainen L, Laurila IP (2009c) Cereal yield trends in northern European conditions: changes in yield potential and its realisation. Field Crops Res 110: 85-90

Peltovuori T (2008) Precision of commercial soil testing practice for phosphorus fertilizer recommendations in Finland. Agric Food Sci 8:299-308

> Rötter RP, Palosuo T, Pirttioja NK, Dubrovsky M and others

Submitted: January 5, 2015; Accepted: May 29, 2015
(2011) What would happen to barley production in Finland if global warming exceeded $4^{\circ} \mathrm{C}$ ? A model-based assessment. Eur J Agron 35:205-214

Rötter RP, Palosuo T, Kersebaum KC, Angulo C and others (2012) Simulation of spring barley yield in different climatic zones of Northern and Central Europe: a comparison of nine crop models. Field Crops Res 133:23-36

Rötter RP, Höhn J, Trnka M, Fronzek S, Carter TR, Kahiluoto $H$ (2013) Modelling shifts in agroclimate and crop cultivar response under climate change. Ecol Evol 3:4197-4214

Rötter RP, Tao F, Höhn J, Palosuo T (2015) Use of crop simulation modelling to aid ideotype design of future cereal cultivars. J Exp Bot 66:3463-3476

Saarela I, Salo Y, Vuorinen M (2006) Effects of repeated phosphorus fertilisation on field crops in Finland. 1. Yield responses on clay and loam soils relation to soil test $\mathrm{P}$ values. Agric Food Sci 15:106-123

Sacks WJ, Kucharik CJ (2011) Crop management and phenology trends in the US Corn Belt: impacts on yields, evapotranspiration and energy balance. Agric Meteorol 151:882-894

Salo T, Eurola M, Rinne M, Seppälä A, Kaseva J, Kousa T (2014) The effect of nitrogen and phosphorus concentrations on nutrient balances of cereals and grass silage. MTT Report147, MTT Agrifood Research Finland, Jokioinen

Salonen J, Hyvönen T, Kaseva J, Jalli H (2013) Impact of changed cropping practices on weed occurrence in spring cereals in Finland - a comparison of surveys in 1997-1999 and 2007-2009. Weed Res 53:110-120

Semenov MA, Stratonovitch P, Alghabari F, Gooding MJ (2014) Adapting wheat in Europe for climate change. J Cereal Sci 59:245-256

Song Y, Chen D, Dong W (2006) Influence of climate on winter wheat productivity in different climate regions of China, 1961-2000. Clim Res 32:219-227

Taylor SL, Payton ME, Raun WR (1999) Relationship between mean yield, coefficient of variation, mean square error, and plot size in wheat field experiments. Commun Soil Sci Plant Anal 30:1439-1447

Tester M, Langridge P (2010) Breeding technologies to increase crop production in a changing world. Science 327:818-822

> Tubiello FN, Amthor JS, Boote KJ, Donatelli M and others (2007) Crop response to elevated $\mathrm{CO}_{2}$ and world food supply: a comment on 'Food for thought ...' by Long et al., Science 312:1918-1921, 2006. Eur J Agron 26:215-223

van Ittersum MK, Rabbinge R (1997) Concepts in production ecology for analysis and quantification of agricultural input-output combinations. Field Crops Res 52:197-208

van Ittersum MK, Cassman KG, Grassini P, Wolf J, Tittonell P, Hochman Z (2013) Yield gap analysis with local to global relevance - a review. Field Crops Res 143:4-17

> van Oort PAJ, Timmermans BGH, Meinke H, van Ittersum MK (2012) Key weather extremes affecting potato production in The Netherlands. Eur J Agron 37:11-22

Ylivainio K, Sarvi M, Lemola R, Uusitalo R, Turtola E (2014) Regional $\mathrm{P}$ stocks in soil and in animal manure as compared to P requirement of plants in Finland. MTT Report 124, MTT Agrifood Research Finland, Jokioinen

> Zadoks JC, Chang TT, Konzak CF (1974) A decimal code for the growth stages of cereals. Weed Res 14:415-421

Proofs received from author(s): September 7, 2015 